\title{
Geoelectrical Variations in Residential Area of Ojongbodu, Oyo, Southwestern Nigeria
}

\author{
T.A. Adagunodo $* \dagger$ and O.P. Oladejo** \\ *Department of Physics, Covenant University, Ota, Nigeria \\ ***Department of Physics, Emmanuel Alayande College of Education, Oyo, Nigeria \\ †Corresponding author: T.A. Adagunodo; theophilus.adagunodo@ covenantuniversity.edu.ng
}

Nat. Env. \& Poll. Tech. Website: www.neptjournal.com

Received: 09-11-2019

Revised: 03-12-2019

Accepted: 16-01-2020

Key Words:

Geoelectrical variations

Lithological variations

Residential area

Structural failure

\begin{abstract}
This study is aimed at mapping the geoelectrical variations in the residential area of Ojongbodu, Oyo, Nigeria. Thirty vertical electrical sounding stations were occupying across the study area using PZ-02 Earth resistivity meter. Four subsurface layers involving topsoil, two weathered layers and bedrock were mapped, with clay being the most dominating soil type in the third layer, which is about $3.9 \mathrm{~m}$ below the first two layers. The thickness of the third layer itself is about $10.4 \mathrm{~m}$. About $70 \%$ of the bedrock is fractured. The thickness of clay in the third layer cum fractured bedrock could aid development of differential settlements in buildings or total collapse of structures within the study area.
\end{abstract}

\section{INTRODUCTION}

One of the human physiological needs on earth is shelter or building. It protects the man from the local environment and gives one feeling of well-being. Structures can be used for commercial, residential, industrial, institutional, entertainment and religious purposes. Unfortunately, a building that supposes to satisfy human's need has become worrisome to man as a result of its failure. The two causes of building failure, as identified by Sunmonu (2018) are structural and cosmetic failures. Structural failure occurs when addition or subtraction of material is made to the building, which affects both its stability and outlook. Cosmetic failure occurs when the effect is only on the outlook of the building. In other words, the building is considered to have failed when it could no longer fulfil its functions and be relied upon for safety again.

The alarming rate of building collapses in Nigeria today is very high (Sunmonu 2018). Most people believed that these collapses are due to usage of substandard material without considering the lithological variations. Electrical resistivity (ER) method has been a proven and reliable tool in the assessment of near-surface structures for civil engineering purpose (Olatinsu et al. 2018). It is considered as the best in comparison to the geotechnical investigation, because of its ability to produce 3-D subsurface imaging and its cost (Adewoyin et al. 2017).
In this study, the ER method involving Schlumberger array was used to determine the geoelectrical variations of each delineated lithology in the residential area of Ojongbodu, Oyo, Nigeria. This study aims to characterize the geoelectrical sequence of the study area, to map out the thickness of clayey zone to determine its civil engineering worthiness. Structural failure is not only peculiar to Nigeria, but it has also become a global concern. Some of the structural failure incidences across the globe have been documented in Omenihu et al. (2016), Sunmonu (2018), and Wikipedia-Structural Failure (2019). Among numerous studies that have employed geophysical approach for civil engineering investigations include Adewoyin et al. (2017), Adagunodo et al. (2018), and Olatinsu et al. (2018).

Nigeria is on the Pan-African mobile belt, which is an integral of the remobilized basement rocks of West Africa. The two major geological formations that spread in equal proportion are the sedimentary Basins (Upper Cretaceous in age) (Bayowa et al. 2019, Joel et al. 2019, Usikalu et al. 2018) and Basement rocks (Precambrian in age) (Olafisoye et al. 2012, Oladejo et al. 2013, Orosun et al. 2019). The study area resides over the Basement complex rocks of southwestern Nigeria (Fig.1). These Basement rocks are either igneous or metamorphic. Locally, some of the available rocks around the study area include older granite, quartzites, marble, laterites, and quartzofeldspathic biotite schists (Adagunodo et al. 2018). 


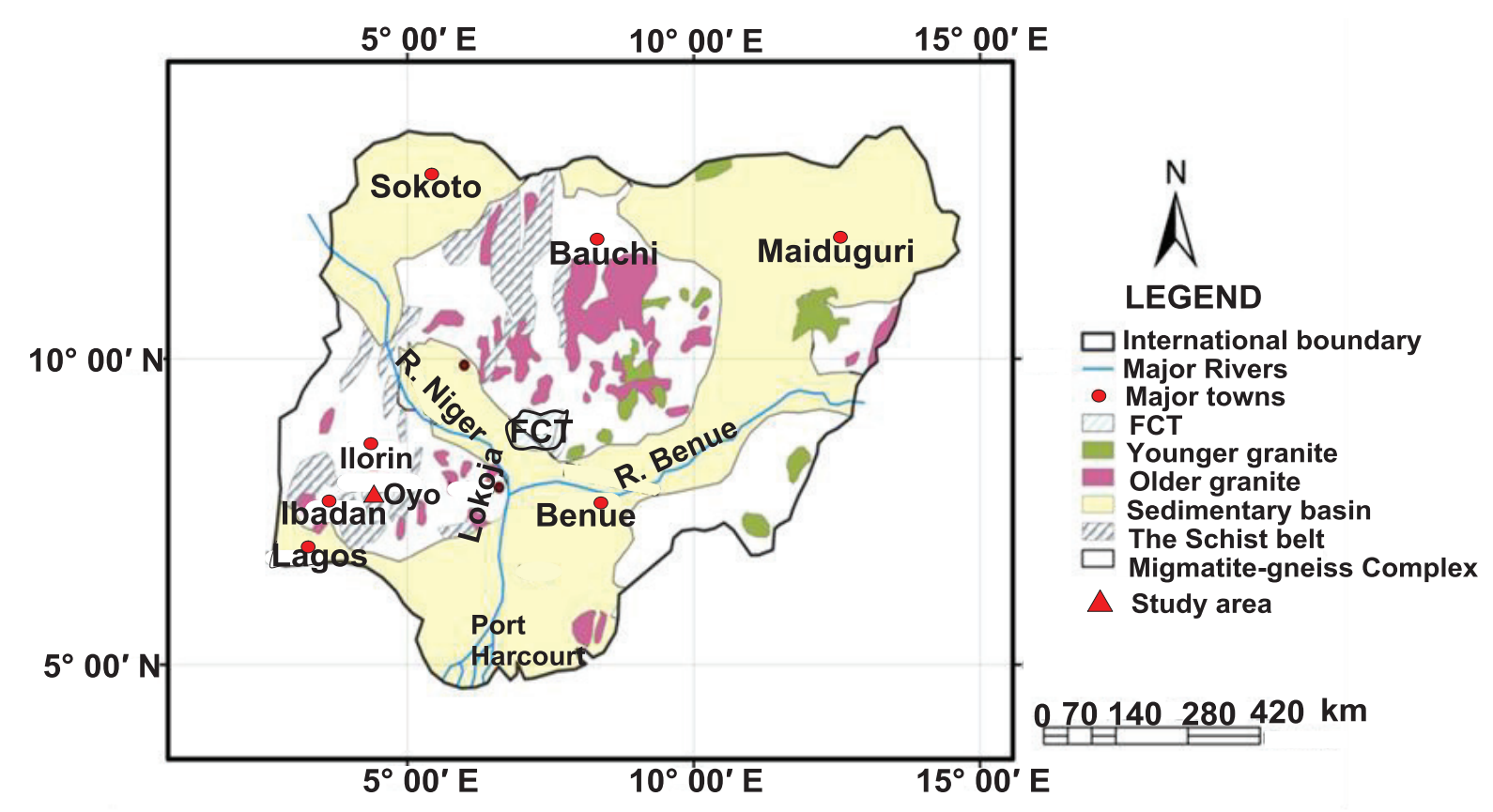

Fig. 1: Geological domains of Nigeria (Adapted from Adagunodo et al. 2019).

\section{MATERIALS AND METHODS}

A PZ-02 Earth meter was used to acquire Vertical Electrical Sounding (VES) data from thirty different stations in the study area (Fig. 2). The field data acquisition was randomly collected to cover the study area, which is bounded by latitude $07^{\circ} 50^{\prime} 00^{\prime \prime}$ to $07^{\circ} 52^{\prime} 12^{\prime \prime}$ north and longitude $03^{\circ} 54^{\prime} 51^{\prime \prime}$ to $03^{\circ} 56^{\prime} 00^{\prime \prime}$ east. The apparent resistivity ( ${ }_{\text {a }}$ ) was determined through the product of the measured resistance and the geometric factor (which is a function of the spacing of the electrode array used) as documented by Koefoed (1979). Partial curve matching involving the plot of apparent resistivity against the current electrode spacing was used to produce the first field thickness and resistivity of each layer (first layer parameters). An automated approach known as WinResist was used to produce the final layers parameters (from the field data and the first layer parameters), which are capable of revealing the geoelectrical sequences of the study area.

\section{RESULTS AND DISCUSSION}

The geoelectrical parameters of each layer are revealed in Fig. 3. According to the classifications of Koefoed (1979), and Sunmonu et al. (2015), maximum of four subsurface layers were mapped. The prominent constituents of the topsoil in the study area are clay and laterites. These two soil types transcend to the second layer with the identification of the weathered layer, which could be interpreted as either sandy clay or clayey sand. In the third layer, about $65 \%$ of this layer is composed of clay, while the southern region is composed of weathered layer and compacted sands. The fourth layer constitutes the bedrock, which is composed of either fractured or fresh bedrock. About $70 \%$ of the study area is underlain by fractured bedrock, an indicative of incompetent location for the construction of mega structures. The mean thicknesses of topsoil, second and third layers are 1.3, 2.6 and $10.4 \mathrm{~m}$, respectively. Clay is composed of minuscule particles that depict hard rock-like when dry, and a sticky mixture when wet. This property enables clay to swell and shrink during the rainy and dry seasons, respectively. The thickness of clay in the third layer could aid development of differential settlements in buildings or total collapse of structures within the study area. In order not to compromise the integrity of building foundations in the study area, mats are recommended for the construction of conventional shallow foundations. However, deep foundations such as piles or caissons are recommended for the construction of mega structures. This will enable the load of the buildings not to be transmitted directly on the clayey zone, which could result in vertical movement of the foundations during seasonal variations.

\section{CONCLUSION}

This study has been able to reveal the heterogeneous nature of subsurface. Four layers that were delineated in the study area are topsoil, second and third layers, as well as the 


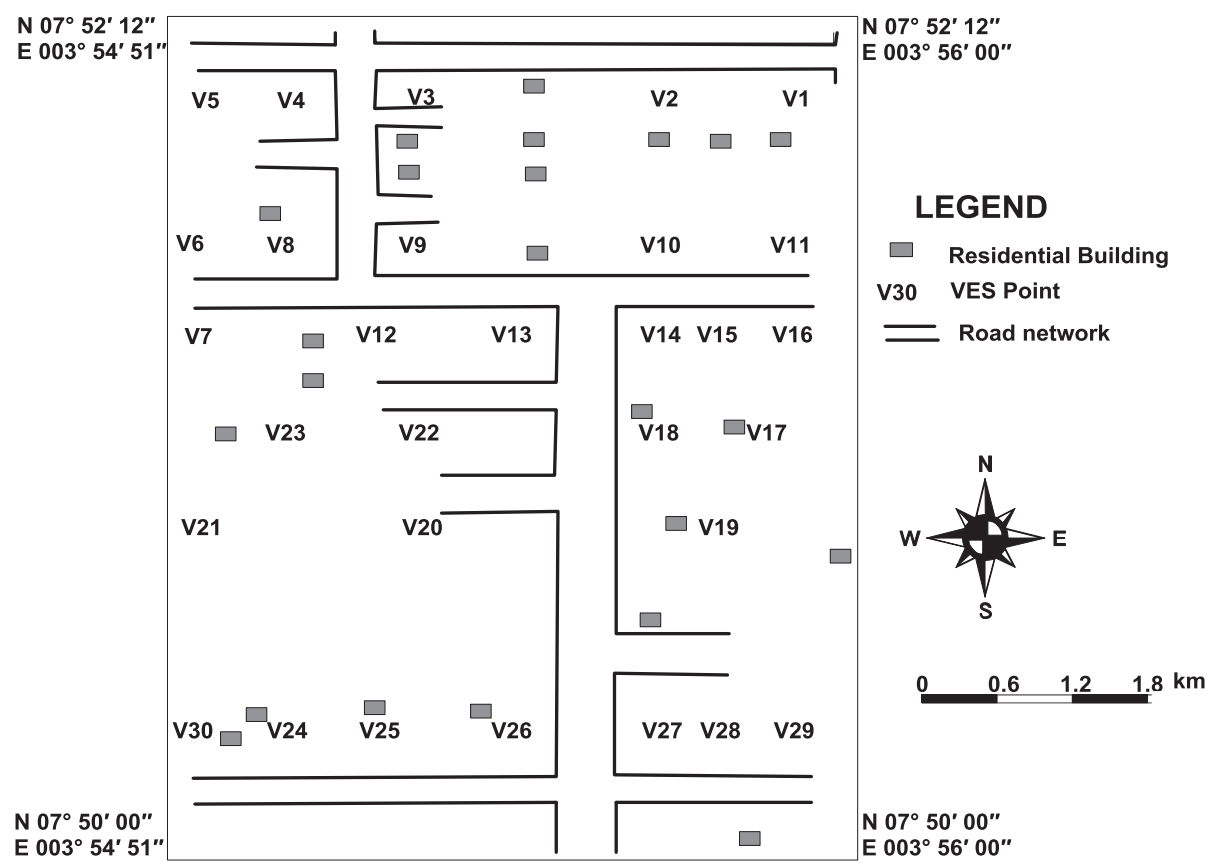

Fig. 2: VES stations within the study area.

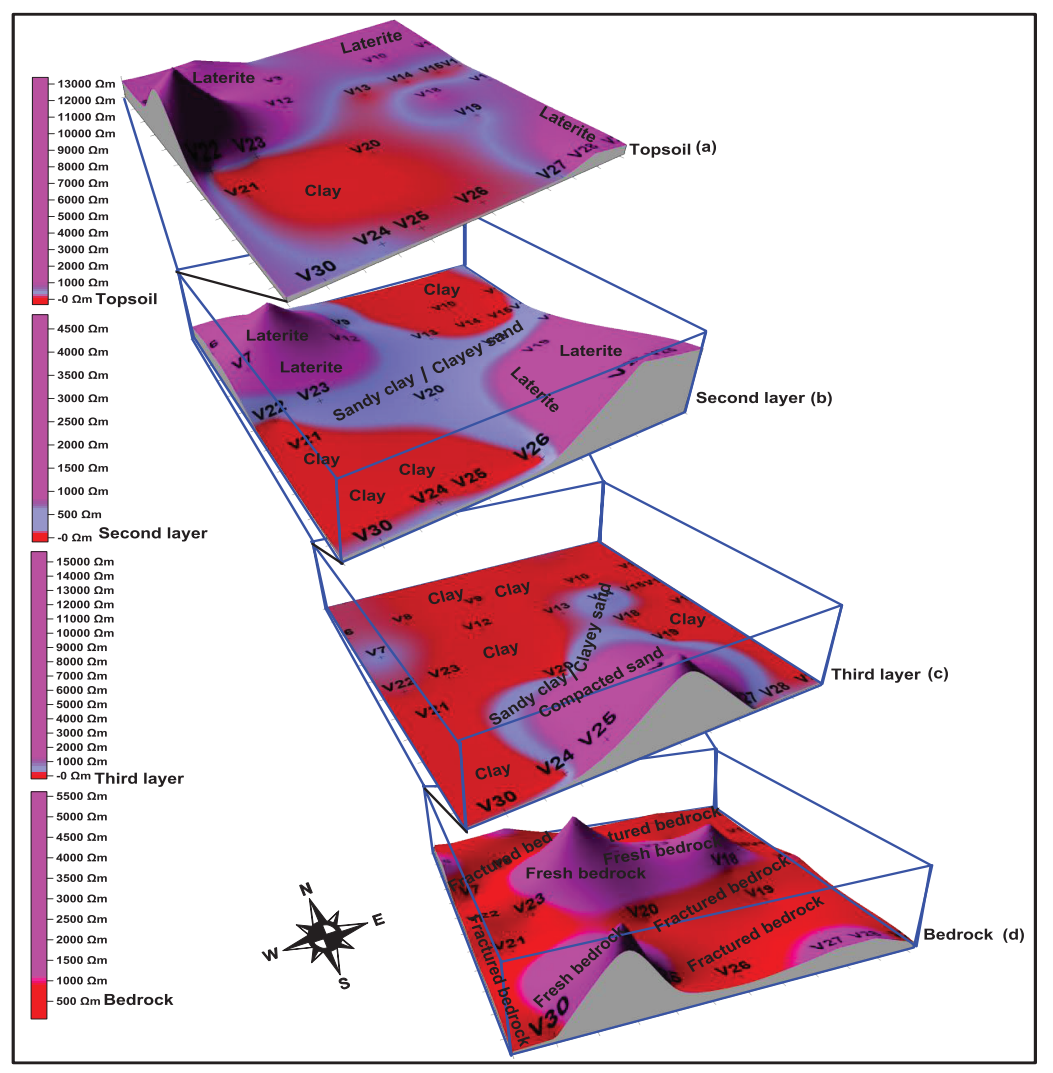

Fig. 3: Geoelectrical variations across each layer in the study area. 
bedrock. Thick clay constitutes the third layer, while about $70 \%$ of the bedrock is fractured. Geoelectrical sequences in the study area have shown that competent hands (that is, certified builders) are only worthy of constructing buildings in the residential area of Ojongbodu, Oyo, Nigeria.

\section{ACKNOWLEDGEMENT}

Partial support from Covenant University, Nigeria is appreciated.

\section{REFERENCES}

Adagunodo, T.A., Sunmonu, L.A., Oladejo, O.P., Hammed, O.S., Oyeyemi, K.D. and Kayode, O.T. 2018. Site characterization of Ayetorohousing scheme, Oyo, Nigeria. IOP Conference Series: Earth and Environmental Science, 173: 012031 .

Adagunodo, T.A., Sunmonu, L.A., Oladejo, O.P. and Olanrewaju, A.M. 2019. Characterization of soil stability to withstand erection of highrise structure using electrical resistivity tomography. In: Kallel A. et al. (eds.). Recent Advances in Geo-Environmental Engineering, Geomechanics and Geotechnics, and Geohazards. Advances in Science, Technology and Innovation (IEREK Interdisciplinary Series for Sustainable Development).

Adewoyin, O.O., Joshua, E.O., Akinwumi, I.I., Omeje, M. and Joel, E.S. 2017. Evaluation of geotechnical parameters using geophysical data. J. Eng. Technol. Sci., 49(1): 95-113.

Bayowa, O.G., Adagunodo, T.A. and Oyedara, I.I. 2019. Reservoir classification and petrophysical evaluation of "BAO" Field, Niger Delta. Petroleum and Coal, 61(5): 1112- 1119.

Joel, E.S., Olasehinde, P.I., Adagunodo, T.A., Omeje, M., Akinyemi, M.L. and Ojo, J.S. 2019. Integration of aeromagnetic and electrical resistivity imaging for groundwater potential assessment of coastal plain sands area of Ado-Odo/Ota in Southwest Nigeria. Groundwater for Sustainable Development, 9: 100264.

Koefoed, O. 1979. Geosounding Principles, I. Resistivity Sounding Measurements. Elsevier Scientific Publishing, Comp. Amsterdam.

Oladejo, O.P., Sunmonu, L.A., Ojoawo, A., Adagunodo, T.A. and Olafisoye, E.R. 2013. Geophysical investigation for groundwater development at Oyo State Housing Estate Ogbomosho, Southwestern Nigeria. Research Journal of Applied Sciences, Engineering and Technology, 5(5): 18111815 .

Olafisoye, E.R., Sunmonu, L.A., Ojoawo, A., Adagunodo, T.A. and Oladejo, O.P. 2012. Application of very low frequency electromagnetic and hydro-physicochemical methods in the investigation of groundwater contamination at Aarada waste disposal site, Ogbomoso, Southwestern Nigeria. Australian Journal of Basic and Applied Sciences, 6(8): 401-409.

Olatinsu, O.B., Oyedele, K.F. and Ige-Adeyeye, A.A. 2018. Electrical resistivity mapping as a tool for post-reclamation assessment of subsurface condition at a sand-filled site in Lagos, Southwestern Nigeria. SN Applied Sciences, 1:24.

Omenihu, F.C., Onundi, L.O. and Alkali, M.A. 2016. An analysis of building collapse in Nigeria (1971-2016): Challenges for Stakeholders. Annals of Borno, XXVI: 113-140.

Orosun, M.M., Usikalu, M.R., Oyewumi, K.J. and Adagunodo, T.A. 2019. Natural radionuclides and radiological risk assessment of granite mining field in Asa, North-Central Nigeria. MethodsX, 6C: 2504-2514.

Sunmonu, L.A. 2018. The good and the bad of faults: A geophysical perspective. Inaugural Lecture Series 25. Ladoke Akintola University of Technology, Nigeria. ISBN: 978-2902-82-9.

Sunmonu, L.A., Adagunodo, T.A., Adeniji, A.A., Oladejo, O.P. and Alagbe, O.A. 2015. Geoelectric delineation of aquifer pattern in crystalline bedrock. Open Transactions on Geosciences, 2(1): 1-16.

Usikalu, M.R., Oderinde, A., Adagunodo, T.A. and Akinpelu, A. 2018. Radioactivity concentration and dose assessment of soil samples in cement factory and environs in Ogun State, Nigeria. International Journal of Civil Engineering and Technology, 9(9): 1047-1059.

Wikipedia-Structural Failure, 2019. List of structural failures and collapses. Retrieved on July 6, 2019. 